\title{
Obituaries
}

\section{SIR WILLIAM PATON}

(1917-1993)

Sir William Paton, FRS, Honorary Director of the Wellcome Institute from 1983 to 1987, and a member of the Editorial Board of this journal for the past decade, died on 17 October 1993, aged 76.

Bill Paton's principal career was in experimental pharmacology, and from his student days he was marked for distinction. He took first class honours at Oxford University and won gold medals during his clinical training at University College Hospital. He was a Reader at the age of 35, a Professor two years later, and a Fellow of the Royal Society before he was 40. He returned to Oxford as Professor of Pharmacology in 1959, retiring in 1984. His pioneering research on the drug therapy of hypertension, the pathophysiology and treatment of diving sickness, the pharmacology of smooth muscle relaxants and a number of other topics will ensure his place in the history of twentieth-century medical science. He also collected committees like some people collect postage stamps or old coins, sitting (by his own count) on seventy-two, as chairman of many of them. For much of his later career, he spent almost as much time in London as he did in Oxford, though he still managed to run a large and productive Department of Pharmacology in Oxford.

It was his appointment as a Wellcome Trustee in 1978 which led ultimately to his happy association with the Institute. Even before then, British historians of science and medicine had reason to appreciate him. He encouraged the Royal Society to take seriously its responsibilities in the history of science, editing (with Professor R. V. Jones) Notes and records of the Royal Society for more than two decades and serving on the British National Committee for the History of Science, Medicine and Technology for almost as long. As chairman of the BNCHSMT, he worked effectively to increase representation on it of professional historical groups and to encourage high standards in the discipline.

His own historical interests were manifested in his superb library, choice volumes from which have come to the Wellcome Institute; in his generous endowment of historical funds in the Physiological Society and British Pharmacological Society; and in several papers and lectures and the historical sense which permeated his last book, Man and mouse, the second edition of which appeared shortly before his death.

Although his brief period as Honorary Director of the Wellcome Institute was marred by his declining health, it was a happy time in the Institute's history. He identified with the Institute and its staff and aided its development. During the "Paton years", the daily running of the Institute was the responsibility of a trio of Eric Freeman, Steve Emberton and Bill Bynum. When Bill Paton was too unwell to come to London, committee meetings were held in his house in Oxford, where the high point was tea with Bill and Phoebe.

W. F. Bynum 